\title{
The Intercultural Identities of Nonnative English Teachers: An Overview of Research Worldwide
}

\author{
Dadi Chen ${ }^{1}$, Dineke E.H. Tigelaar ${ }^{1} \&$ Nico Verloop ${ }^{1}$ \\ ${ }^{1}$ ICLON, Leiden University Graduate School of Teaching, Leiden University, The Netherlands \\ Correspondence: Dadi Chen, ICLON, Leiden University Graduate School of Teaching, Leiden University, P.O. \\ Box 905, 2300 AX Leiden, The Netherlands. Tel: 31-620-127818.
}

Received: June 17, 2016

Accepted: July 5, 2016

Online Published: July 11, 2016

doi:10.20849/aes.v1i2.48

URL: http://dx.doi.org/10.20849/aes.v1i2.48

\begin{abstract}
Nonnative-English-speaking teachers who teach English as a second or foreign language (ESL/EFL) can play an important role in the promotion of intercultural competence and often have an advantage over native-English-speaking ESL/EFL teachers because they once were language learners and more aware of the difficulties that students can encounter. Therefore, a better understanding is needed of nonnative ESL/EFL teachers in language-and-culture teaching contexts. Research on how these teachers view themselves in relation to two or more cultural groups, i.e., teachers' intercultural identities is useful in this respect, but has been scarce. In the present study, we systematically reviewed 21 studies on the intercultural identities of nonnative ESL/EFL teachers. Our study provides insight in key characteristics of these teachers' intercultural identities, factors in the formation of these teachers' intercultural identities, inconsistencies in studies to date, and directions for further research.
\end{abstract}

Keywords: nonnative English-speaking teacher, English language as a second language (ESL), English language as a foreign language (EFL), teacher identity, intercultural identity

\section{Introduction}

Teachers who teach English as a second or foreign language (ESL/EFL) play an important role in not only helping learners learn the language but also preparing learners for future intercultural communication (Council of Europe, 2001). Such teachers must, for example, teach their students about the cultures of English-speaking countries (often shortened to 'ES cultures') (Cortazzi \& Jin, 1999) and unavoidably compare ES cultures with their own cultures. However, teachers are not merely 'technicians' who simply adopt right methods to reach the teaching target (Varghese, Morgan, Johnston, \& Johnson, 2005). Considering the sociocultural background of teachers, for example, it is difficult for teachers to be neutral and objective when thinking about different cultures (Byram, Gribkova, \& Starkey, 2002). Starting from the observation that more than $80 \%$ of English teachers are nonnative teachers who do not have English as their first language and are not teaching in English-speaking countries (Braine, 2010), their understanding of ES cultures can be expected to vary widely along with their positions and roles of teaching about ES cultures. The weight that ESL/EFL teachers give to intercultural knowledge, skills, and attitudes of students — often referred to as their intercultural communicative competence' (see Byram (1997) or just 'intercultural competence') — will also vary accordingly (Sercu et al., 2005).

Earlier studies have shown that ESL/EFL teachers in different countries have different notions of themselves when it comes to teaching ES cultures (Menard-Warwick, 2008; Weisman, 2001; Wette \& Barkhuizen, 2009). The teachers also have different ideas about why, how and what they should teach about these cultures (Moran, 2001; Sercu et al., 2005). To better understand just how teachers teach cultures in different countries, how teachers see their roles in teaching about cultures, and how ESL/EFL teaching worldwide helps cultivate intercultural competence, we must gain insight into how ESL/EFL teachers regard themselves within language and culture teaching context. This means, we need a better understanding of how ESL/EFL teachers view themselves in relation to the cultures they teach about. As Varghese et al. (2005) stated:

...in order to understand language teaching and learning we need to understand teachers; and in order to understand teachers, we need to have a clearer sense of who they are: the professional, cultural, political, and individual identities which they claim or which are assigned to them (Varghese et al., 2005, p. 22). 
In the literature the concept of teachers' identities, i.e., their perception of themselves as teachers, has been used to improve our understanding of this issue, and when referring to ESL/EFL teachers in teaching language with intercultural dimension, often the concept of teachers' intercultural identities, i.e., teachers' perceptions of themselves in relation to two or more cultural groups, has been used (Alptekin \& Alptekin, 1984; Gao, 1999; Menard-Warwick, 2008).

Since the beginning of the 1990s, increasing numbers of studies about the self-perceptions of nonnative English-speaking ESL/EFL teachers have been conducted. The scope of the studies has expanded from a native/nonnative English-speaker comparison to observation of professional behavior across different sociocultural contexts (Braine, 2005, 2006, 2010; Moussu \& Llurda, 2008; Samimy \& Kurihara, 2006). The available research has shown that nonnative teachers, in particular, face the challenge of not only helping students solve problems stemming from conflicts between cultures but also develop their own intercultural identities while doing this (Moran, 2001). Nonnative teachers can play a particularly important role in the promotion of intercultural competence and often have an advantage over native English-speaking teachers of ESL/EFL because they once were language learners and more aware of the pitfalls and difficulties that students can encounter. They can share their experience of culture shock with their students if the teachers have once themselves and can help their students to prepare for it (Moussu \& Llurda, 2008). However, the limited amont of relevant research does not provide a clear picture of the intercultural identities of nonnative teachers.

In the present study, we use the term nonnative teachers to refer to nonnative English-speaking professionals with English as a second or foreign language and responsible for the teaching of English to nonnative speakers of languages other than English. We are aware of the long debate on the use of the term 'nonnative' in connection with ESL/EFL teachers (Selvi, 2011). In using this term, we are not referring to the bias against the English language competence of the teachers, nor overlooking the linguistic and cultural varieties among the nonnative teachers but, rather, focusing on a target group of study.

The aim of the present study is to provide an overview of the recent research on the intercultural identities of nonnative English-speaking ESL/EFL teachers (shortened in the following as nonnative teachers) and put forth directions for further research. For this purpose, we conducted a review study. Before presenting our review of the intercultural identities of nonnative teachers, however, we must first clarify a few additional concepts, highlight what is known about the intercultural identities of nonnative teachers, and pinpoint what is lacking in the existing literature. For the sake of clarity, it should be noted that we will use 'identity' and 'intercultural identity' to refer to the identity or self of the teacher within a language and culture teaching context in the remainder of this article and offer a more detailed definition of such identity below.

\section{Conceptualizing Intercultural Identities of Nonnative Teachers}

Identity can be defined as the individual's sense of who he or she is during the ongoing interaction with the world (Erikson, 1963). The concepts of identity and self are often blurred (White \& Ding, 2009, p. 336). According to Beijaard, Meijer, and Verloop (2004), a teacher's identity is constantly developing and involves two strongly interwoven sides: the teacher's own ideas accumulated on the basis of personal experience and the ideas or expectations imposed upon the teacher by the social context. In other words, both person and context are implied in this conceptualization of 'teacher identity.' In addition, the notion of teacher identity may involve different sub-identities depending on the context (Beijaard et al., 2004). More integrated, dynamic conceptualizations of language teachers' identity suggest that identity clearly depends on the social, cultural, and political context and develops via language and discourse (Faez, 2011; Gee, 2001; Rivers \& Ross, 2013; Varghese et al., 2005).

In many studies about language teaching and learning, identity theories are used as a lens through which to view teaching in relation to the classroom practice (Gee, 2001; Norton, 2006). This means that the identity of a language teacher is seen as a crucial component not only in 'determining how language teaching is played out' within the classroom, but also in understanding the 'sociocultural and sociopolitical landscape of the language classroom' (Varghese et al., 2005, p. 22). Previous studies into intercultural identity are often focused on immigrants (including teacher or student sojourners) or cultural groups and their developing views of themselves in relation to more than one culture (Flunger \& Ziebertz, 2010; Kim, 1994). Alptekin and Alptekin (1984) used the term 'intercultural identity' firstly when describing the target of EFL teaching. In recent studies of nonnative ESL/EFL teachers, the concept of teachers' intercultural identity has been used, investigating how these teachers viewed themselves from a sociocultural and pedagogical perspective (e.g., Duff \& Uchida, 1997; Ilieva, 2010; Liu, 1999; Nugroho Widiyanto, 2005). The studies just mentioned, shows very different pictures and expectations of nonnative teachers, and a clearer view is needed on what characterizes the intercultural identities 
of teachers, and how the identities of these teachers are formed in language and culture teaching contexts. In particular, it is necessary to conduct a review of the present studies about the in-service teachers, because their experiences of teaching and intercultural communication will shed light on the forming of teachers' intercultural identities.

In the present review, we examined recent studies of the intercultural identities of nonnative teachers across different countries. All of the studies were published in peer-reviewed journals with a worldwide circulation. And on the basis of this literature, we hoped to be able to increase our understanding of the characteristics and formation of the intercultural identities of nonnative teachers in particular and thus pave the way for future studies of their unique position and roles for the teaching of English and intercultural competence. The following two research questions were addressed in our review.

1) How are the intercultural identities of nonnative English-speaking ESL/EFL teachers characterized and defined in recent studies?

2) What do these studies report about the formation of the intercultural identities of nonnative English-speaking ESL/EFL teachers?

\section{Method}

\subsection{Data Collection}

We searched the following international databases for articles on the identities of nonnative English-speaking ESL/EFL teachers: ISI (including JSTOR), ERIC, PsycINFO, and Springerlink. In addition, we searched Google Scholar and the references of the selected articles. We limited our search to peer-reviewed articles based on empirical studies published between 1997 and 2015 so as to obtain an overview of acknowledged state-of-the-art achievements in the field and avoid the dangerous 'inflationist repetition of the same ideas in different words' found in non-empirical articles (Moussu \& Llurda, 2008).

Considering various alternative labels that might be used for 'nonnative English-speaking teachers,' 'ESL/EFL,' 'intercultural', and 'identity,' we initially run a preliminary search in title, key words, and abstracts of articles by using various combinations of keywords. The combinations included (a) 'nonnative teacher' and 'ESL/EFL' and 'intercultural/cross-cultural/cultural' and 'identity/self,' (b) 'nonnative teacher' and 'English/TESOL' and 'intercultural/cross-cultural/cultural' and 'identity/self,' and (c) 'nonnative teacher' and 'English/TESOL' and 'identity/self' and 'culture.' The search with the combinations yielded no hit. We tried to enlarge the scope of search by replacing 'nonnative teacher' by 'teacher' in each of the combinations, or searched in the full text of articles with these combinations.

In the end, we identified 59 articles and narrowed this down to 21 articles meeting the following inclusion criteria:

- Focus on only in-service nonnative ESL/EFL teachers (43 articles met this criterion; 10 articles were excluded because both nonnative English-speaking and native English-speaking teachers were included (but not distinguished) or teachers of other subjects were included (but not distinguished); 6 articles were excluded because they studied pre-service teachers).

- Keywords in the title or the article such as cultural, or intercultural identity/awareness/self or identity in intercultural/cross-cultural context (21 articles met this criterion; 22 papers were excluded because the use of the words in the enlarged search led to topics of little or no relevance to the present study (e.g., transnationalism, cultural capital, identity status) or consideration of only the linguistic or pedagogical qualities of nonnative teachers without attention to cultural issues).

\subsection{Data Analysis}

In order to answer our research questions, we categorized the 21 selected articles into two groups: (a) those concerned with the characteristics of teacher identities; (b) those concerned with dynamic processes shaping teacher identities.

For each article, we gave an overview of the characteristics of the study (see Tables 1 and 2 for more information). We labeled the studies with the previous (if the teachers were trainees at the time of studies) or present types of the English teachers participating in the studies, i.e., ESL or English as a second language (in English-speaking regions or countries, e.g., the United States, Australia, Hong Kong) and EFL or English as a foreign language (in non-English-speaking countries, e.g., Belgium, Chile, China, Vietnam). 


\section{Characteristics of the Identities of Nonnative Teachers}

Studies of the identities of nonnative teachers have only recently been initiated (Braine, 2010). The 21 articles qualifying for our review and thus published between 1997 and 2015 were selected from only 59 articles published in peer-reviewed journals. Fourteen of the studies were about nonnative English-speaking EFL teachers from Belgium, Brazil, Bulgaria, Chile, China (mainland), Colombia, Greece, Indonesia, Japan, Korea, Mexico, Poland, Spain, Sweden, and Vietnam, and seven studies about nonnative ESL teachers in Australia, Canada, Hong Kong, and the United States (see methodology in Tables 1 and 2).

Table 1. Overview of studies included in the review on characteristics of intercultural identities of nonnative English-Speaking ESL/EFL teachers

\begin{tabular}{|c|c|c|c|c|c|}
\hline $\begin{array}{c}\text { Author, } \\
\text { year / type } \\
\text { of teachers }\end{array}$ & Aim of study & $\begin{array}{c}\text { Concept and } \\
\text { definition } \\
\text { adopted* }\end{array}$ & $\begin{array}{l}\text { Related } \\
\text { concepts }\end{array}$ & Methodology & Main findings \\
\hline $\begin{array}{l}\text { Liu (1999) } \\
\text { / ESL }\end{array}$ & $\begin{array}{l}\text { To explore the } \\
\text { complexities of } \\
\text { the labels } \\
\text { native/nonnativ } \\
\mathrm{e} \\
\text { English-speaker } \\
\text { and relevant } \\
\text { consequences } \\
\text { in teaching }\end{array}$ & $\begin{array}{l}\text { Nonnative } \\
\text { English-speaki } \\
\text { ng TESOL } \\
\text { professional or } \\
\text { dual identities; } \\
\text { no explicit } \\
\text { definition }\end{array}$ & $\begin{array}{l}\text { native/nonnat } \\
\text { ive } \\
\text { English-spea } \\
\text { ker } \\
\text { dichotomy; } \\
\text { cultural } \\
\text { affiliation }\end{array}$ & $\begin{array}{l}\text { Data gathered from } \\
\text { e-mail and } \\
\text { interviews with } 7 \\
\text { nonnative } \\
\text { English-speaking } \\
\text { TESOL } \\
\text { professionals in the } \\
\text { United States }\end{array}$ & $\begin{array}{l}\text { The participants interpreted the } \\
\text { term 'nonnative } \\
\text { English-speaking professional in } \\
\text { TESOL' in various ways. } \\
\text { Their diverse backgrounds and } \\
\text { experiences revealed complex } \\
\text { dimensions of the label, } \\
\text { involving the sequence in which } \\
\text { the languages were learned, } \\
\text { competence in English, cultural } \\
\text { affiliation, self-identification, } \\
\text { social environment, and political } \\
\text { labeling. }\end{array}$ \\
\hline $\begin{array}{l}\text { Weisman } \\
(2001) / \\
\text { ESL }\end{array}$ & $\begin{array}{l}\text { To examine } \\
\text { bicultural } \\
\text { identities of } \\
\text { bilingual } \\
\text { teachers and } \\
\text { their attitudes } \\
\text { towards English } \\
\text { and Spanish as } \\
\text { well as the } \\
\text { relationship } \\
\text { between the } \\
\text { two languages }\end{array}$ & $\begin{array}{l}\text { Bicultural } \\
\text { identity } \\
\text { described in } \\
\text { terms of the } \\
\text { individual's } \\
\text { identification } \\
\text { with cultural } \\
\text { groups; no } \\
\text { explicit } \\
\text { definition }\end{array}$ & Biculturalism & $\begin{array}{l}\text { Interviews with } 4 \\
\text { Latino teachers in } \\
\text { the United States; } \\
\text { data examined for } \\
\text { expressed attitudes, } \\
\text { contradictions, and } \\
\text { conceptualizations } \\
\text { concerning key } \\
\text { issues related to } \\
\text { language and } \\
\text { culture }\end{array}$ & $\begin{array}{l}\text { Differences between teachers' } \\
\text { bicultural identities appear in } \\
\text { their ways of coping with } \\
\text { pressures in a society that } \\
\text { encourages conformity to the } \\
\text { dominant culture; there are } \\
\text { connections between: bicultural } \\
\text { identity and political } \\
\text { consciousness; teachers' } \\
\text { bicultural identities and language } \\
\text { attitudes; and identification with } \\
\text { Latino culture, political } \\
\text { consciousness, and recognition } \\
\text { of the value of the Spanish } \\
\text { language as a means to affirm } \\
\text { the cultural identities of Latino } \\
\text { students. }\end{array}$ \\
\hline $\begin{array}{l}\text { Sercu } \\
(2002) / \\
\text { EFL }\end{array}$ & $\begin{array}{l}\text { To inquire into } \\
\text { how foreign } \\
\text { language } \\
\text { teachers' } \\
\text { current } \\
\text { professional } \\
\text { self-concepts } \\
\text { and teaching } \\
\text { practices relate } \\
\text { to the } \\
\text { envisaged }\end{array}$ & $\begin{array}{l}\text { Teachers, } \\
\text { professional } \\
\text { self-concept } \\
\text { operationalized } \\
\text { in terms of } \\
\text { knowledge, } \\
\text { attitudes, skills } \\
\text { needed to } \\
\text { develop } \\
\text { learners' } \\
\text { intercultural }\end{array}$ & $\begin{array}{l}\text { Intercultural } \\
\text { communica-ti } \\
\text { ve } \\
\text { competence }\end{array}$ & $\begin{array}{l}\text { Questionnaire } \\
\text { survey in Belgium } \\
\text { among } 78 \text { teachers } \\
\text { of English, } 45 \\
\text { teachers of French, } \\
\text { and } 27 \text { teachers of } \\
\text { German }\end{array}$ & $\begin{array}{l}\text { Participating teachers were } \\
\text { willing to support intercultural } \\
\text { objectives. Their teaching } \\
\text { practices, however, cannot be } \\
\text { characterized as directed towards } \\
\text { the full attainment of } \\
\text { intercultural communicative } \\
\text { competence. }\end{array}$ \\
\hline
\end{tabular}


profile of the intercultural

foreign

language

teacher

Llurda and

Huguet

(2003) /

EFL

EFL

Sercu

(2006) /

EFL

Diniz de

Figueiredo

(2011)/

ESL

Guerrero

Nieto and

Meadows

(2015)

/EFL of nonnative teacher of 'foreign language and intercultural competence' $\mathrm{g}$ teachers in schools identities in various relationships and novice teachers

competence; no

explicit

definition

To uncover the self-perception

English-speakin g EFL teachers

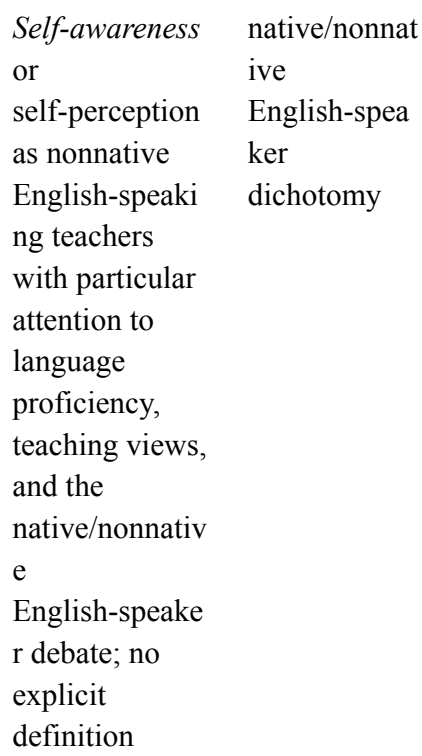

Questionnaire survey of 101 nonnative English-speaking primary and secondary school English language teachers in the city of Lleida, Spain

Professional self-concept; intercultural communica-ti ve competence

specifications put forth for a

To investigate how nonnative English-speakin American K-12 perceive their

\section{To investigate} how dialogues between expert
Foreign

language and intercultural competence teachers, referring seemingly to teachers who possess the knowledge, skills, and attitudes to teach intercultural competence; no explicit definition

Teachers' identities defined as both self-perception and image as observed by others

Global
professional
identity,
meaning a
globally-minde

Teachers' beliefs profiled over 7 countries (Belgium, Bulgaria, Greece, Mexico, Poland, Spain, Sweden) by means of a web-based questionnaire native/nonnat ive English speaker dichotomy
Survey with 19 open questions of 15 Brazilian ESL teachers working in elementary and middle schools in the United States

None

Case study based on the thematic analysis of (a) the online dialogue between 14 expert
Compared to primary school teachers, secondary school teachers showed (a) a higher regard for their own language skills, (b) a higher preference for a communicative orientation in teaching, and (c) stronger critical awareness of their situation as nonnative English-speaking teachers in teaching English as an international language.
Teachers' profiles do not yet meet those of the envisaged 'foreign language and intercultural competence teacher'; different patterns in teacher thinking and teaching practice found.
The teachers' language skills were crucial in defining their identities as nonnative English-speaking teachers. Native/nonnative English speaker dichotomy still affects the ways in which the teachers are perceived.

(a) Teachers considered different contextual factors, e.g., teaching experience, coursework, in the online dialogue. (b) Expert and novice teachers differed in 


$\begin{array}{ll}\begin{array}{ll}\text { provide them } \\ \text { with spaces to }\end{array} & \begin{array}{l}\mathrm{d} \text { professional } \\ \text { identity, aware }\end{array} \\ \text { activate critical } & \text { that 'any } \\ \text { awareness of } & \text { teaching } \\ \text { their global } & \text { context is } \\ \text { professional } & \text { situated at both } \\ \text { identity. } & \text { global and } \\ & \text { local scales } \\ & \text { simultaneously } \\ & \text { '(p.14) }\end{array}$

$\begin{array}{ll}\begin{array}{l}\text { nonnative } \\ \text { English-speaking } \\ \text { English language } \\ \text { teachers in }\end{array} & \begin{array}{l}\text { consider the role of English } \\ \text { language teaching (ELT), } \\ \text { institutional constraints, whose } \\ \text { culture to teach, and linguistic } \\ \text { diversity in language teaching. } \\ \text { novice nonnative }\end{array} \\ \begin{array}{l}\text { English-speaking } \\ \text { teachers the United } \\ \text { sensitive to the dangers of } \\ \text { colonialism and they supported a } \\ \text { critical perspective between ES } \\ \text { cultures and their own. The } \\ \text { attended graduate } \\ \text { programs in }\end{array} & \begin{array}{l}\text { novice teachers considered } \\ \text { teacher education }\end{array} \\ \begin{array}{l}\text { American culture as the focus of } \\ \text { at the same time } \\ \text { and (b) the }\end{array} & \begin{array}{l}\text { instruction and future selves as } \\ \text { representatives of American } \\ \text { interviews with } \\ \text { culture. }\end{array} \\ \begin{array}{l}\text { those 12 teachers in } \\ \text { the United States } \\ \text { about the dialogue }\end{array} & \end{array}$

Note. * The terms in italics are those concepts used in the studies.

The first category of studies provides insight into the characteristics of the identities of nonnative teachers in language and culture teaching contexts where they must deal with differing cultures, values, and norms (see Table 1 for an overview).

\subsection{Aims of the Studies}

The studies in this group were designed to explore the identities of nonnative teachers in various pedagogical, institutional, and sociocultural relationships either inside or outside the classroom setting. The aims of the studies varied as the contexts of the teachers were different. The aims of the studies with teachers working, living, or studying in a ES country addressed the identities of the teachers within various sociocultural and institutional relationships (Liu, 1999; Weisman, 2001); they also explored the connections between the identities of the teachers and their attitudes towards sociocultural relationships, languages, cultures, and their teaching expertise (Diniz de Figueiredo, 2011; Weisman, 2001).

The aims of the studies of nonnative teachers in their home countries were mainly to define and describe their identities within institutional relationships and thus in relation to native English-speaking colleagues (Llurda \& Huguet, 2003) or specifically from the perspective of the need to promote intercultural competence among students (Sercu, 2002, 2006). Guerrero Nieto and Meadows (2015) brought expert and novice nonnative EFL teachers together in dialogue with an aim to explore the teachers' critical awareness of a professional identity as situated in teaching context with both global and local scales.

\subsection{Definitions}

As shown in Table 1, various terms were used to describe the intercultural identities of the nonnative teachers: cultural affiliation, dual identity (Liu, 1999), bicultural identity (Weisman, 2001), or global professional identity (Guerrero Nieto \& Meadows, 2015). Most of the terms were not explicitly defined and could only be interpreted according to their context of use.

The identity concepts varied depending on the focus and perspective of research: identity as a sense of belonging to a certain culture (Liu, 1999), identification with a cultural group within society (Weisman, 2001), professional qualification (e.g., language skills, teaching views) within the teaching context (Diniz de Figueiredo, 2011; Llurda \& Huguet, 2003), awareness of professional identity in both global and local teaching context (Guerrero Nieto \& Meadows 2015), or ability to teach intercultural competence (Sercu, 2002, 2006). In some of the studies, a native/nonnative English-speaking dichotomy was quoted as this was presumably an important aspect of the identities of nonnative teachers in these contexts (Diniz de Figueiredo, 2011; Liu, 1999; Llurda \& Huguet, 2003).

\subsection{Related Concepts}

Related concepts in these articles included the native/nonnative English speaker dichotomy and intercultural competence. The attitudes and positions of nonnative teachers with respect to the native/nonnative English speaker debate were considered important for their self-perceptions (Diniz de Figueiredo, 2011; Liu, 1999; 
Llurda \& Huguet, 2003). Intercultural communicative competence, consisting of the intercultural knowledge, skills, and attitudes relating to both the teacher's native culture and the foreign culture which the teachers is teaching, helped to define a competent foreign language teacher also (Sercu, 2002, 2006).

\subsection{Methods}

Four out of the 7 empirical studies were conducted as small-scale interviews, classroom observations, or questionnaires with open questions; the other 3 were large-scale surveys. Teachers' knowledge, attitudes, and judgments with respect to their identities, language teaching, and student responses were given much more weight in the studies than their teaching behavior. Both qualitative and quantitative approaches were adopted. Qualitative approaches allow the researchers to examine teacher identity in depth in a specific context and not to extrapolate generalizations beyond the immediate setting (Guerrero Nieto \& Meadows 2015). Quantitative approaches, however, enable the researchers to draw individual results together and consider them as a totality to show trends and divergence among different countries or groups (Sercu et al., 2005).

\subsection{Main Findings}

With regard to the characteristics of the identities of the nonnative teachers, the teachers often perceive and evaluate themselves in terms of the following: their language proficiency and ability to teach, their relationships with various parties in the school and society, conflicts they have encountered, and their sociocultural experiences (see the last column of Table 1). The specific pedagogical settings and sociocultural backgrounds of the teachers also appeared to be of major importance for their intercultural identities.

The way in which the teachers label their identities is closely connected to their sociocultural backgrounds and experiences, and they appear to be aware of the interactions between this labeling and their professional functioning. Liu (1999), for example, reports that the environment in which people are exposed to languages plays a crucial role in their definition of the 'non/native English-speaking TESOL professional' and their '(perceived) competence in English, cultural affiliations, self-identification, social environment, and political labeling'. Guerrero Nieto and Meadows (2015) found in their study that expert teachers recalled their working experience and teaching context when reflecting on their identities, while novice teachers resorted to their learning experience to imagine their future identities.

The self-perceptions of linguistic proficiency and awareness of the pedagogical advantages of being a nonnative teacher as opposed to a native English-speaking teacher proved important for the identities of the nonnative teacher. This is illustrated by the findings of both Llurda and Huguet (2003) and Diniz de Figueiredo (2011). Not only the English-language competence of nonnative teachers contribute to how they identify themselves in the workplace but also their bilingual or multilingual skills and ability to relate to the cultures of their students and the parents of their students (Diniz de Figueiredo, 2011). In addition, the self-concepts of the teachers can develop as they narrow the gap between their actual teaching profiles and their ideal profiles of foreign language teachers who are willing and competent to teach intercultural competence (Sercu, 2002, 2006), or as novice teachers communicate with expert teachers in dialogue (Guerrero Nieto \& Meadows, 2015).

Further variation in the intercultural identities of the nonnative teachers was found to depend on their self-narratives and thus relate to their political, linguistic and cultural attitudes. Weisman (2001), for example, found teachers to vary between having only a vague sense of belonging to a certain culture versus a strong sense of belonging. They showed very different cultural orientations that could range from complying with the expectations of the mainstream culture in the ES country (i.e., the United States) to retaining the teacher's native cultural identity. A strong connection was also detected by Weisman between the identities of the teachers and their awareness of the status of language and culture within society, on the one hand, and their attitudes towards their mother tongue and the English language, on the other hand. Teachers may consider their roles differently in relation to the cultures they teach. Guerrero Nieto and Meadows $(2015$, p. 22) found expert teachers supported critical view of the home and target cultures in class, while novice teachers considered that they would 'represent for their students authentic American English and culture'. 
Table 2. Overview of studies included in review of formation of intercultural identities of nonnative English-speaking ESL/EFL teachers

\begin{tabular}{|c|c|c|c|c|c|}
\hline $\begin{array}{l}\text { Author and year / } \\
\text { type of teachers }\end{array}$ & Aim of the study & $\begin{array}{l}\text { Concept and } \\
\text { definition } \\
\text { adopted* }\end{array}$ & $\begin{array}{l}\text { Related } \\
\text { concepts }\end{array}$ & Methodology & Main findings \\
\hline $\begin{array}{l}\text { Duff and Uchida } \\
\text { (1997) / EFL }\end{array}$ & $\begin{array}{l}\text { To explore } \\
\text { teachers' roles } \\
\text { and identities as } \\
\text { instructors and } \\
\text { purveyors of } \\
\text { (American) } \\
\text { English language } \\
\text { and cultures in } \\
\text { Japan }\end{array}$ & $\begin{array}{l}\text { Sociocultural } \\
\text { identity } \\
\text { (sometimes } \\
\text { interchanged } \\
\text { with cultural } \\
\text { identity), } \\
\text { seemingly } \\
\text { referring to how } \\
\text { the teachers } \\
\text { perceive their } \\
\text { role in this } \\
\text { sociocultural } \\
\text { context; no } \\
\text { explicit } \\
\text { definition }\end{array}$ & $\begin{array}{l}\text { Professional, } \\
\text { social, political, } \\
\text { and cultural } \\
\text { identities }\end{array}$ & $\begin{array}{l}4 \text { EFL teachers } \\
\text { and their classes } \\
\text { in Japan as the } \\
\text { subject of an } \\
\text { ethnographic case } \\
\text { study plus data } \\
\text { collected via } \\
\text { questionnaires, } \\
\text { weekly } \\
\text { retrospective } \\
\text { journal entries, } \\
\text { audio/videotaped } \\
\text { classroom } \\
\text { observations, field } \\
\text { notes, interviews, } \\
\text { review of } \\
\text { instructional } \\
\text { materials, and the } \\
\text { research journal } \\
\text { of teachers }\end{array}$ & $\begin{array}{l}\text { The teachers' perceptions of } \\
\text { their sociocultural identities } \\
\text { were found to be formed and } \\
\text { constantly developed on the } \\
\text { basis of their personal } \\
\text { histories, past educational, } \\
\text { professional, and (cross-) } \\
\text { cultural experiences. } \\
\text { Language teachers socialize } \\
\text { students in new cultural } \\
\text { practices. } \\
\text { Teachers are involved in } \\
\text { cultural transmission. }\end{array}$ \\
\hline $\begin{array}{l}\text { Nugroho } \\
\text { Widiyanto (2005) } \\
\text { / ESL }\end{array}$ & $\begin{array}{l}\text { To discuss a } \\
\text { range of social } \\
\text { and cultural } \\
\text { influences on his } \\
\text { emerging identity } \\
\text { as a teacher of } \\
\text { English }\end{array}$ & $\begin{array}{l}\text { Identity, always } \\
\text { connected to } \\
\text { race, religion, } \\
\text { and social status } \\
\text { in reflection; no } \\
\text { explicit } \\
\text { definition }\end{array}$ & None & $\begin{array}{l}\text { Self-study of an } \\
\text { Indonesian } \\
\text { teacher of English } \\
\text { via autobiography } \\
\text { and critical } \\
\text { reflection }\end{array}$ & $\begin{array}{l}\text { He discusses in a } \\
\text { self-reflective manner the } \\
\text { types of discourses at work to } \\
\text { construct his identity in a } \\
\text { range of different settings. }\end{array}$ \\
\hline $\begin{array}{l}\text { Phan and Phan } \\
(2006) / E F L\end{array}$ & $\begin{array}{l}\text { To analyze the } \\
\text { nature of } \\
\text { Vietnamese } \\
\text { teacher identity } \\
\text { constructions and } \\
\text { the relations } \\
\text { between the } \\
\text { personal, } \\
\text { professional, and } \\
\text { morality of } \\
\text { teachers }\end{array}$ & $\begin{array}{l}\text { Identity as } \\
\text { 'being' and } \\
\text { 'becoming' } \\
\text { (stability within } \\
\text { changes); } \\
\text { identity as } \\
\text { national/cultural } \\
\text { entity and sense } \\
\text { of belonging }\end{array}$ & $\begin{array}{l}\text { (national) } \\
\text { morality }\end{array}$ & $\begin{array}{l}\text { Individual/group } \\
\text { interviews and } \\
\text { guided reflective } \\
\text { writing with } 7 \\
\text { Vietnamese } \\
\text { teachers of } \\
\text { English in } \\
\text { Australian } \\
\text { TESOL programs }\end{array}$ & $\begin{array}{l}\text { Despite being teachers of } \\
\text { English, teachers' } \\
\text { morality-related identities } \\
\text { remained persistent. They } \\
\text { negotiated their identities } \\
\text { alongside morality and moral } \\
\text { values in their cultural and } \\
\text { professional practices. They } \\
\text { presented a strong sense of } \\
\text { self as a teacher in relation to } \\
\text { morality and cultural model } \\
\text { of the moral guide role. }\end{array}$ \\
\hline $\begin{array}{l}\text { Phan }(2007) / \\
\text { EFL }\end{array}$ & $\begin{array}{l}\text { To examine the } \\
\text { identity } \\
\text { formation of the } \\
\text { teachers, with } \\
\text { regard to their } \\
\text { negotiations of } \\
\text { their seemingly } \\
\text { conflicting roles } \\
\text { and selves }\end{array}$ & $\begin{array}{l}\text { National/cultura } \\
\text { l identity, noted } \\
\text { as constructed, } \\
\text { multiple, and } \\
\text { dynamic with } \\
\text { sense of } \\
\text { belonging in } \\
\text { relation to } \\
\text { mobility and the } \\
\text { construction of } \\
\text { national identity; }\end{array}$ & None & $\begin{array}{l}\text { Case study of } 7 \\
\text { Vietnamese } \\
\text { teachers of } \\
\text { English (six } \\
\text { females and one } \\
\text { male) studying } \\
\text { TESOL at } \\
\text { different } \\
\text { Australian } \\
\text { universities; data } \\
\text { collected through }\end{array}$ & $\begin{array}{l}\text { The results show that a strong } \\
\text { sense of a Vietnamese } \\
\text { national/cultural identity is } \\
\text { consistently constructed and } \\
\text { confirmed by the teachers, } \\
\text { despite their global mobility. }\end{array}$ \\
\hline
\end{tabular}


no explicit
definition

Tsui (2007) / EFL To understand the processes of identity formation, the interplay between processes and identities as teachers position themselves

Menard-Warwick (2008) / ESL

Yang and Bautista (2008) / EFL

\section{To explore the} connections between the development of teachers' intercultural competence and their transnational life experiences; how they define their own (inter)cultural identities; and how they approach cultural issues with their students

To investigate how a Korean teacher of English (re)shaped her teacher self through reflective and interrelated negotiations with herself and others
Identity seems to None refer to teachers' professional identity; no explicit definition

\section{Intercultural} identity as 'a negotiated investment in seeing the world through multiple cultural lenses' (p.622)

Identity and
teacher self,
connected to a
necessary 'self'
confrontation in
varying forms in
and outside the
classroom; no
explicit
definition

individual

in-depth

interviews, focus group interviews, and guided reflective writing
The process of self-identification interacts with the participation in negotiating meanings. The interplay of identification and the negotiability of meanings could generate identity conflicts.

The two female teachers developed their bicultural identity through their past experiences in two cultures. They were observed to differ somewhat in their approaches to the teaching of cultural issues.

\begin{tabular}{ll}
$\begin{array}{l}\text { A Korean English } \\
\text { teacher enrolled }\end{array}$ & $\begin{array}{l}\text { Korean teachers of English } \\
\text { struggle to establish their own } \\
\text { as participant, }\end{array}$ \\
identity against the \\
background of continuous \\
ideas about her & $\begin{array}{l}\text { compliance with values, } \\
\text { Standards, and norms for }\end{array}$ \\
Korean English & $\begin{array}{l}\text { individual, school, and } \\
\text { teacher identity in } \\
\text { a letter }\end{array}$ \\
& $\begin{array}{l}\text { society; this struggle can } \\
\text { result in positive } \\
\text { transformations. }\end{array}$ \\
\hline
\end{tabular}




\begin{tabular}{|c|c|c|c|c|c|}
\hline $\begin{array}{l}\text { Fotovatian (2010) } \\
\text { / EFL }\end{array}$ & $\begin{array}{l}\text { To describe } \\
\text { nonnative } \\
\text { English-speaking } \\
\text { teachers' struggle } \\
\text { to construct a } \\
\text { social and } \\
\text { professional } \\
\text { identity }\end{array}$ & $\begin{array}{l}\text { Social and } \\
\text { professional } \\
\text { identity (social } \\
\text { identity referring } \\
\text { seemingly to a } \\
\text { sense of } \\
\text { belonging to a } \\
\text { community, and } \\
\text { professional } \\
\text { identity related } \\
\text { to native-like } \\
\text { proficiency and } \\
\text { competence as a } \\
\text { teacher of } \\
\text { English); no } \\
\text { explicit } \\
\text { definition }\end{array}$ & $\begin{array}{l}\text { Intercultural } \\
\text { interaction } \\
\text { strategies }\end{array}$ & $\begin{array}{l}\text { Interview with } 2 \\
\text { Iranian teachers of } \\
\text { English in an } \\
\text { Australian } \\
\text { university; } \\
\text { audio-recording } \\
\text { of team } \\
\text { conversation and } \\
\text { the participants' } \\
\text { electronic journals }\end{array}$ & $\begin{array}{l}\text { Teachers value social } \\
\text { interactions as the major } \\
\text { channel for integration and } \\
\text { networking; } \\
\text { Their isolation resulted from } \\
\text { cultural gaps, difficulty in } \\
\text { engagement in local } \\
\text { discourses, and asymmetrical } \\
\text { power relationship and } \\
\text { legitimacy. }\end{array}$ \\
\hline $\begin{array}{l}\text { Ilieva (2010) / } \\
\text { EFL }\end{array}$ & $\begin{array}{l}\text { To explore and } \\
\text { analyze } \\
\text { nonnative } \\
\text { teachers' } \\
\text { negotiations of } \\
\text { TESOL program } \\
\text { discourses in the } \\
\text { process of } \\
\text { developing } \\
\text { identities }\end{array}$ & $\begin{array}{l}\text { Teaching/profess } \\
\text { ional identities; } \\
\text { identity } \\
\text { understood as } \\
\text { critically related } \\
\text { to social, } \\
\text { cultural, and } \\
\text { political } \\
\text { contexts, } \\
\text { constructed and } \\
\text { negotiated } \\
\text { through } \\
\text { language and } \\
\text { discourse; } \\
\text { multiple, } \\
\text { shifting, and in } \\
\text { conflict; no } \\
\text { explicit } \\
\text { definition }\end{array}$ & None & $\begin{array}{l}\text { The Bakhtinian } \\
\text { analysis of } \\
\text { portfolios from } 20 \\
\text { Chinese teachers } \\
\text { of English in a } \\
\text { Canadian TESOL } \\
\text { program }\end{array}$ & $\begin{array}{l}\text { Despite being teachers of } \\
\text { English, their morality-related } \\
\text { identities persisted. } \\
\text { The process of identity } \\
\text { formation consolidates their } \\
\text { understanding of identity as } \\
\text { dynamic and a sense of } \\
\text { belonging. }\end{array}$ \\
\hline $\begin{array}{l}\text { Menard-Warwick } \\
(2011) / \text { EFL }\end{array}$ & $\begin{array}{l}\text { To explore } \\
\text { teachers' } \\
\text { perspectives on } \\
\text { their own } \\
\text { bilingual identity } \\
\text { development } \\
\text { through their } \\
\text { appropriation of } \\
\text { English language } \\
\text { popular culture } \\
\text { across five } \\
\text { decades }\end{array}$ & $\begin{array}{l}\text { Teacher } \\
\text { (bilingual) } \\
\text { identity } \\
\text { considered to be } \\
\text { pedagogical, } \\
\text { context-depende } \\
\text { nt, and } \\
\text { constructed } \\
\text { through the } \\
\text { appropriation of } \\
\text { voices from } \\
\text { cultures }\end{array}$ & None. & $\begin{array}{l}\text { Interview with } 18 \\
\text { Chilean teachers } \\
\text { of English at a } \\
\text { Chilean } \\
\text { University }\end{array}$ & $\begin{array}{l}\text { There are connections } \\
\text { between popular culture and } \\
\text { bilingual development. } \\
\text { Teachers had multiple } \\
\text { identities. One identity they } \\
\text { all brought to their pedagogy } \\
\text { was that of active second } \\
\text { language user and discerning } \\
\text { popular cultural consumer. }\end{array}$ \\
\hline Reis (2011) / ESL & $\begin{array}{l}\text { To explore the } \\
\text { processes through } \\
\text { which nonnative } \\
\text { teachers can } \\
\text { achieve a sense } \\
\text { of professional } \\
\text { identity } \\
\text { legitimacy 'by }\end{array}$ & $\begin{array}{l}\text { Professional } \\
\text { /teacher } \\
\text { identity/self, } \\
\text { used } \\
\text { interchangeably } \\
\text { in reference to } \\
\text { the } \\
\text { understanding of }\end{array}$ & None & $\begin{array}{l}\text { A dialogic } \\
\text { journal, } \\
\text { videotaped } \\
\text { classroom } \\
\text { observations, } \\
\text { audio-taped } \\
\text { interviews, } \\
\text { teaching }\end{array}$ & $\begin{array}{l}\text { The participant went from } \\
\text { being a 'blind believer' in the } \\
\text { native-speaker myth to } \\
\text { challenging it; worked to } \\
\text { empower own students as } \\
\text { expert speakers and users of } \\
\text { the language. His beliefs and } \\
\text { attitudes toward the NS myth }\end{array}$ \\
\hline
\end{tabular}




\begin{tabular}{|c|c|c|c|c|c|}
\hline & $\begin{array}{l}\text { being empowered } \\
\text { to recognize, } \\
\text { acknowledge, and } \\
\text { contest } \\
\text { ideological } \\
\text { discourses that } \\
\text { position them as } \\
\text { second-rate } \\
\text { professionals' (p. } \\
\text { 141) }\end{array}$ & $\begin{array}{l}\text { oneself in } \\
\text { relation to } \\
\text { sociocultural } \\
\text { context, social } \\
\text { relationships, } \\
\text { and activity in } \\
\text { the world }\end{array}$ & & $\begin{array}{l}\text { philosophy } \\
\text { statements, } \\
\text { student surveys } \\
\text { about a Chinese } \\
\text { teacher of a } \\
\text { graduate-level } \\
\text { English writing } \\
\text { course in the } \\
\text { United States }\end{array}$ & $\begin{array}{l}\text { remained ambivalent and } \\
\text { contradictory. }\end{array}$ \\
\hline $\begin{array}{l}\text { Wu and } \\
\text { Wurenbilige } \\
(2012) / \text { EFL }\end{array}$ & $\begin{array}{l}\text { To investigate the } \\
\text { identity of a } \\
\text { (Chinese) } \\
\text { Mongolian } \\
\text { teacher of } \\
\text { English at } \\
\text { university, her } \\
\text { own perceived } \\
\text { identity, and } \\
\text { factors } \\
\text { influencing } \\
\text { identity } \\
\text { formation in } \\
\text { sociocultural } \\
\text { contexts }\end{array}$ & $\begin{array}{l}\text { Teacher identity, } \\
\text { referring to the } \\
\text { knowledge of } \\
\text { 'who I am' and } \\
\text { 'what kind of } \\
\text { person I am'; } \\
\text { dynamic; } \\
\text { developing over } \\
\text { lifetime; } \\
\text { reinterpreted and } \\
\text { reshaped while } \\
\text { interacting with } \\
\text { social and } \\
\text { cultural } \\
\text { community }\end{array}$ & None & $\begin{array}{l}\text { Interview of a } \\
\text { (Chinese) } \\
\text { Mongolian } \\
\text { trilingual teacher } \\
\text { of English in a } \\
\text { Chinese } \\
\text { university }\end{array}$ & $\begin{array}{l}\text { The teacher's identity is } \\
\text { complex: a (Chinese) } \\
\text { Mongolian person, a Chinese } \\
\text { speaker, and a university } \\
\text { teacher of English. Her } \\
\text { identity formation was } \\
\text { influenced by many factors } \\
\text { such as her living } \\
\text { environment, family } \\
\text { background, and employment } \\
\text { context with learning } \\
\text { experiences playing a very } \\
\text { crucial role. }\end{array}$ \\
\hline $\begin{array}{l}\text { Trent (2012) / } \\
\text { ESL }\end{array}$ & $\begin{array}{l}\text { To explore how } \\
\text { the experiences } \\
\text { of teaching a } \\
\text { language and its } \\
\text { sociocultural } \\
\text { aspects shape the } \\
\text { professional } \\
\text { identities of a } \\
\text { beginning } \\
\text { English language } \\
\text { teacher in Hong } \\
\text { Kong. }\end{array}$ & $\begin{array}{l}\text { Teacher identity } \\
\text { as 'our } \\
\text { understanding of } \\
\text { who we are and } \\
\text { who we think } \\
\text { other people are' } \\
\text { (Danielewicz, } \\
\text { cited in Trent, } \\
\text { 2012) }\end{array}$ & None & $\begin{array}{l}\text { Three-rounds of } \\
\text { interviews with } 8 \\
\text { nonnative } \\
\text { teachers of } \\
\text { English in Hong } \\
\text { Kong (with results } \\
\text { of } 2 \text { rounds } \\
\text { reported in article) }\end{array}$ & $\begin{array}{l}\text { The participants' engagement } \\
\text { in the practices and activities } \\
\text { of teaching, their relations } \\
\text { with colleagues, and their } \\
\text { positioning within different } \\
\text { discourses of teaching and } \\
\text { learning by their schools as } \\
\text { well as by the wider } \\
\text { educational environment } \\
\text { shaped their decisions about } \\
\text { whether to continue to pursue } \\
\text { a teaching career. }\end{array}$ \\
\hline $\begin{array}{l}\text { Ortaçtepe (2015) / } \\
\text { EFL }\end{array}$ & $\begin{array}{l}\text { To explore how } 2 \\
\text { EFL teachers' } \\
\text { language } \\
\text { socialization in } \\
\text { the United States } \\
\text { to enable them to } \\
\text { (re)construct their } \\
\text { identities as } \\
\text { teachers of } \\
\text { intercultural } \\
\text { competence. }\end{array}$ & $\begin{array}{l}\text { Teachers of } \\
\text { intercultural } \\
\text { competence } \\
\text { seem to refer to } \\
\text { 'language } \\
\text { teachers who } \\
\text { teach the target } \\
\text { language with its } \\
\text { cultural } \\
\text { dimension' (p. } \\
96)\end{array}$ & $\begin{array}{l}\text { intercultural } \\
\text { communica- } \\
\text { tive } \\
\text { competence; } \\
\text { language } \\
\text { socialization }\end{array}$ & $\begin{array}{l}\text { Interviews with } 2 \\
\text { experienced } \\
\text { Turkish EFL } \\
\text { teachers coming } \\
\text { to the United } \\
\text { States for } \\
\text { graduate study; } \\
\text { the 3-phased } \\
\text { interviews } \\
\text { comprised the } \\
\text { participants' past, } \\
\text { present, and } \\
\text { future over } 9 \\
\text { months }\end{array}$ & $\begin{array}{l}\text { The language socialization of } \\
\text { the } 2 \text { teachers in the United } \\
\text { States led to personal } \\
\text { transformations in their } \\
\text { identity as teachers of } \\
\text { intercultural competence. And } \\
\text { such identity also enabled } \\
\text { them to reflect on their } \\
\text { current and future language } \\
\text { and culture teaching practice. } \\
\text { Teacher identities are } \\
\text { dynamic, situated, multiple, } \\
\text { and even sometimes blurred. }\end{array}$ \\
\hline
\end{tabular}

Note. ${ }^{*}$ The terms in italics are the concepts used in the studies. 


\section{Formation of the Identities of Nonnative Teachers}

The second category of studies explored the formation of the intercultural identities of nonnative teachers. The factors influencing the formation of teachers' identities were associated with the teachers' sociocultural including intercultural - experiences. These factors were described as constantly developing in conjunction with changing contextual elements that include the family, classroom, school, and society. Most of the factors affecting the teachers' ongoing identity formation appeared to arise from, e.g., discrepancy between language in teaching in the home country and language in use in the ES country (Ortaçtepe, 2015), the teachers problems of socialization in the ES country (Fotovatian, 2010), or a conflict or collision of values from different cultures (Nugroho Widiyanto, 2005) (see Table 2).

\subsection{Aims of the Studies}

Many of the studies of identity formation focused on how identities were formed and negotiated as part of transnational life (Menard-Warwick, 2008; Nugroho Widiyanto, 2005), formed by discourses with regard to TESOL training or PhD program in ES countries (Fotovatian, 2010; Ilieva, 2010; Ortaçtepe, 2015; Phan, 2007), or formed by teaching experiences in teachers' home countries (Tsui, 2007; Wu \& Wurenbilige, 2012; Yang \& Bautista, 2008).

In other studies of the formation of the identities of nonnative teachers, the stated purpose often included both observation of identity formation in order to understand it and search for related factors, including the cultural content of the ESL curricula (Duff \& Uchida, 1997), educational morality (Phan \& Phan, 2006), popular English-language culture (Menard-Warwick, 2011), and other teaching factors (Trent, 2012) (see Table 2).

\subsection{Definitions}

The terms used in the studies of identity formation either implicitly or explicitly pointed to sociocultural and institutional background as the context for identity formation. Either the sociocultural and institutional contexts (Duff \& Uchida, 1997; Menard-Warwick, 2011; Nugroho Widiyanto, 2005; Phan, 2007; Phan \& Phan, 2006) or the professionalism of the teachers (Fotovatian, 2010; Ilieva, 2010; Ortaçtepe, 2015; Reis, 2011; Trent, 2012; Tsui, 2007; Wu \& Wurenbilige, 2012; Yang \& Bautista, 2008) were emphasized in the definitions of identities.

Menard-Warwick (2008) was the only author to adopt the term 'intercultural identity,' which was then defined in relation to the perspectives of teachers formed on the basis of their transnational experiences and 'negotiated investment in seeing the world through multiple cultural lenses'. In the remaining studies, the term 'identity' was used more in the sense of teacher/professional identity within a specific intercultural context, such as teaching of English language and culture or studying, working or living in ES cultures.

In the definitions, the identities of the nonnative teachers were also typically characterized as multidimensional (Duff \& Uchida, 1997), involving a sense of belonging (e.g., on the basis of race, nation, religion, social status) (Nugroho Widiyanto, 2005), or in terms of the different roles required in the classroom and beyond (Ortaçtepe, 2015; Yang \& Bautista, 2008). Ortaçtepe (2015), for example, found that the socialization of two Turkish teachers in the United States involved three identities, i.e., an experienced EFL teacher, an L2 user, and a burgeoning scholar, which were often blurred. Several of the definitions included a dynamic element such as 'being and becoming' (Phan \& Phan, 2006), language socialization (Ortaçtepe, 2015), interacting with mobility (Ilieva, 2010; Phan, 2007), or interacting with the social and cultural community over the life time (Nugroho Widiyanto, 2005; Wu \& Wurenbilige, 2012).

In some of the studies, identity formation is defined as a reaction to the conflict between the ideas, values, and norms of different cultures (Phan, 2007) or a reaction to gaps between past and present selves, current self-perceptions, or existing social norms (Yang \& Bautista, 2008). And such conflict is seen to result in stress, confusion, or dilemma in the formation of a teacher's identity in a multi-cultural context (Nugroho Widiyanto, 2005).

\subsection{Related Concepts}

References to such concepts as professional, political, or cultural identities (Duff \& Uchida, 1997; Menard-Warwick, 2008) reveal the focus of the relevant studies. And particularly the concepts of culture, identity, and interculturality appear to provide the basis for a definition of intercultural identity (Menard-Warwick, 2008).

Other researchers describe the interactions between some related factors and the formation of identity. Phan and Phan (2006) discuss the role of ideology in teachers' development of their identities when part of the teachers' identities remained stable because their morality remained unchanged despite their transnational experience, while Fotovatian (2010) examined the intercultural interaction strategies of teachers in the formation of their 
identities in social integration and professional recognition. Ortaçtepe (2015) explored how language teachers negotiated their identities as teachers of intercultural competence in the language socialization process in the United States. She considers that language teaching needs a cultural dimension, and the development of teachers' identities of intercultural competence requires a socialization process.

\subsection{Methods}

The research on identity formation was conducted in small-scale or individual case studies involving interviews, journals, portfolios, and observations. These qualitative methods helped teachers to reflect upon their identities and transform implicit ideas into well-constructed stories with sometimes considerable depth.

\subsection{Main Findings}

The findings presented in the last column of Table 2 can all be summarized as pointing to some common features of the identity formation of nonnative ESL/EFL teachers.

Teachers develop and negotiate their identities through — often conflicting — interactions or discourses in various sociocultural and institutional contexts, which may include family, local community, religion, classroom, school, and (TESOL) training or postgraduate programs.

Various factors in the interaction between teachers and contexts influence the formation of their identities: their cross-cultural experiences, prior learning or training experiences, relationships with students and colleagues, job demands, and extent of or need for cultural assimilation or socialization.

Various aspects of the identities of nonnative teachers and their attitudes influence each other in the development of their identities within an intercultural context making 'intercultural' crucial for understanding their identity formation. On the one hand, teachers' social, cultural, linguistic, ethnic, political, and professional identities often merge when responding in a particular context. On the other hand, their attitudes towards language, culture, their profession, and power relationships in society can be influenced by their identity development within an intercultural context.

Even within the same sociocultural context, the identities of nonnative teachers can develop differently and thus vary (Duff \& Uchida, 1997; Ilieva, 2010; Menard-Warwick, 2008; Ortaçtepe, 2015). In the study of Menard-Warwick (2008), for example, both participants worked as ESL teachers in the United Students for some years and define themselves as bicultural, but their approaches to teaching cultural issues were different. Their different teaching approaches were connected to their intercultural experiences and institutional contexts. One teacher lived with family members of different cultural backgrounds, and she taught immigrants by comparing frequently her students' cultures with the local culture. The other teacher was impressed by the social changes of her home country and often discussed with her students about such changes brought by globalization. In the study, Menard-Warwick highlighted the value of pedagogical resources of the teachers that they brought in language and culture teaching.

\section{Conclusion}

The studies reviewed here provide insight into how the intercultural identities of nonnative teachers manifest themselves. We found three groups of interrelated factors to shape the intercultural identities of the teachers. (a) Factors related to such traits as personality characteristics; actual and perceived linguistic, intercultural, and teaching competence; ideas towards language and culture; and own experiences with language learning. (b) Factors related to the teaching context, including relationships with colleagues; relationships with nonnative English-speaking students, their parents, and curricula of teaching; and (c) factors related to the more general sociocultural context, which may include the influences from family and society, ideas towards the dominant culture and their own culture; and the transnational experiences of the teacher.

On the basis of our review findings, we can conclude the following about the definition and characteristics of the intercultural identities of nonnative teachers (i.e., research question one). First, the teachers' intercultural identities were found to be flexible and constantly adjusted depending on the challenges and conflicts being confronted by the teachers. Using various means of communication and negotiation, teachers construct and maintain their identities. We saw the conflict between the cultural values of the nonnative ESL/EFL teachers and the local culture of the ES countries to be more manifest among the teacher sojourners than among the teachers in their home countries (i.e., when the teachers were most likely living and working in their own culture). In the ES countries, moreover, the need for the nonnative teachers to identify with the ES culture was more apparent than in their home countries. In their home countries, the identities of EFL teachers are also influenced by ES cultures (e.g., popular music or public media), and education plays an important role in their identity formation (Menard-Warwick (2011). These findings can be useful in cultivating intercultural identities among pre-service 
teachers. As in others' studies, perspective EFL teachers found the exposure to the lifestyles and values of Western people was effective in the formation of their identities (Atay \& Ece, 2009). Sending teachers abroad to study abroad in ES cultures can be a solution (Han \& Yin, 2016). Conscious reflection on their competence and positioning themselves in the community of language teachers also help perspective teachers to form and negotiate their identities in practice (Guerrero Nieto \& Meadows, 2015; Pavlenko, 2003). More studies of how teachers in EFL contexts consider their identities in relation to ES cultures are nevertheless needed.

Second, nonnative teachers are not an undifferentiated group. They develop differing intercultural identities depending on their sociocultural and institutional backgrounds, which can vary from an ES to a non-ES country, from a lower to a higher level of teaching, from novice to expert types of teachers, and from positive to negative responses to various factors at play in the intercultural context of their teaching.

Third, the teachers' confidence in their language skills and intercultural competence influence their intercultural identities, which may then - in turn - influence their attitudes towards languages, teaching, culture, and so forth within the intercultural context.

These three characteristics of the intercultural identities of nonnative ESL/EFL teachers point to both personal and contextual sides of teacher identity, as previously observed by Beijaard et al. (2004).

Although the contexts of the studies we reviewed were all specifically about the teaching of English language and ES cultures or intercultural competence, the labels applied to the intercultural identities of nonnative teachers were sometimes vague and or even nonexistent. We can expect a teacher's identity, professional identity, bilingual identity, sociocultural identity, and intercultural identity actually overlap to such an extent that the boundaries between these labels were blurred. However, to understand how the roles or positions of nonnative teachers are formed in a specific language and culture teaching context and how their roles and positions benefit teaching of ES cultures and intercultural competence, it is advisable to focus on how teachers view themselves in the specific contexts and what they can contribute to language and culture teaching. The teachers' intercultural identity, as one of the sub-identities of their professional identities (the concept 'sub-identity' was proposed by Beijaard et al. (2004)), may be a quite dominant aspect of a nonnative teachers' identity, in particular for those who work in language and culture teaching contexts. More information on just how the teachers regard themselves within specific language and culture teaching contexts is nevertheless needed to provide us insight on how to help teachers to reflect and justify their roles and positions in teaching.

Stepping back, the purpose of the present review was to gain insight into the intercultural identities of nonnative teachers. Knowing about the characteristics of teachers' intercultural identities and the factors that shape them can help teachers reflect upon their identities, and think about how their identities have been formed, how their identities influence their teaching, especially for in-service teachers who may overlook their importance for the teaching of intercultural competence and knowledge of ES cultures or (pre-service) teachers (studying or) working in an environment where ES culture is distant. Reflection on one's intercultural identity may positively affect the teachers themselves and allow them to reject the myth of native speakers always being more qualified than nonnative English-speakers to teach English, for example (Guerrero Nieto \& Meadows, 2015; Reis, 2011). Such reflection may also allow teachers to respond more effectively to the tensions that can arise in teaching contexts from issues such as race, gender, culture, and class (Yang \& Bautista, 2008).

Research on the intercultural identities of nonnative teachers in language and culture teaching contexts has only recently begun to receive widespread attention from researchers and language-teaching professionals. The small number of relevant studies, the limited number of participants in the studies, the limited variety of the participants, and the inconsistency of terminology used lead us to conclude that only limited insight can currently be gained into how teachers in general but also specific countries consider their identities in relation to the target language and culture of their teaching (i.e., ES cultures). As sociocultural theories such as that of Vygotsky became more popular in the study of language pedagogy (Ellis, 2013; van Compernolle \& Williams, 2013), studies of the intercultural identities of teachers shifted their focus more and more to the interaction between sociocultural factors and teachers' perceptions of themselves in the teaching context. More studies comparing nonnative teachers across varying sociocultural and teaching contexts are needed. To enable further exploration of the intercultural identities of nonnative teachers and arrive at fruitful approaches for understanding the formation and roles of their intercultural identities, we need more in-depth case studies and large-scale surveys across countries. Only then can we agree upon the characteristics of the intercultural identities of nonnative teachers, how they are formed, and how they connect to the knowledge, beliefs, attitudes, and behavior of teachers in language and culture teaching contexts. 


\section{References}

Alptekin, C., \& Alptekin, M. (1984). The question of culture: EFL teaching in non-English-speaking countries. ELT Journal, 38(1), 14-20. http://dx.doi.org/10.1093/elt/38.1.14

Atay, D., \& Ece, A. (2009). Multiple identities as reflected in English-language education: The Turkish perspective. Journal of Language, Identity \& Education, 8(1), 21-34. http://dx.doi.org/10.1080/15348450802619961

Beijaard, D., Meijer, P. C., \& Verloop, N. (2004). Reconsidering research on teachers' professional identity. Teaching and Teacher Education, 20(2), 107-128. http://dx.doi.org/10.1016/j.tate.2003.07.001

Braine, G. (2005). Teaching English to the world: History, curriculum, and practice. Mahwah, NJ: Lawrence Erlbaum Associates, Inc.

Braine, G. (2006). A history of research on non-native speaker English teachers. In E. Llurda (Ed.), Non-native language teachers. Perceptions, challenges and contributions to the profession (pp. 13-23). New York: Springer.

Braine, G. (2010). Nonnative speaker Engligh teachers: Research, pedagogy, and professional growth. New York: Routledge.

Byram, M. (1997). Teaching and assessing intercultural communicative competence. Bristol, England: Multilingual Matters.

Byram, M., Gribkova, B., \& Starkey, H. (2002). Developing the intercultural dimension in language teaching: A practical introduction for teachers. Retrieved from http://www.coe.int/t/dg4/linguistic/Source/Guide_dimintercult_En.pdf

Cortazzi, M., \& Jin, L. (1999). Cultural mirrors: Materials and methods in the EFL classroom. In E. Hinkel (Ed.), Culture in second language teaching and learning (pp. 196-219). Cambridge: Cambridge University Press.

Council of Europe. (2001). Common European framework of reference for language learning, teaching and assessment. Cambridge: Cambridge University Press.

Diniz de Figueiredo, E. H. (2011). Nonnative English-speaking teachers in the United States: issues of identity. Language and Education, 25(5), 419-432. http://dx.doi.org/10.1080/09500782.2011.574702

Duff, P. A., \& Uchida, Y. (1997). The negotiation of teachers' sociocultural identities and practices in postsecondary EFL classrooms. TESOL Quarterly, 31(3), 451-486. http://dx.doi.org/10.2307/3587834

Ellis, R. (2013). Changing trends in language teaching research. Language Teaching Research, 17(2), 141-143. http://dx.doi.org/10.1177/1362168812460807

Erikson, E. H. (1963). Childhood and society. New York: W.W.Norton \& Company, Inc.

Faez, F. (2011). Reconceptualizing the native/nonnative speaker dichotomy. Journal of Language, Identity \& Education, 10(4), 231-249. http://dx.doi.org/10.1080/15348458.2011.598127

Flunger, B., \& Ziebertz, H.-G. (2010). Intercultural identity - religion, values, in-group and out-group attitudes. Journal of Empirical Theology, 23(1), 1-28. http://dx.doi.org/10.1163/157092510X503002

Fotovatian, S. (2010). Surviving as an English teacher in the west: A case study of Iranian English teachers in Australia. TESL-EJ, 13(4), 1-10.

Gao, Y. (1999). Understanding and transcending linguistic and cultural differences. Beijing: Foreign Language Teaching and Research Press.

Gee, J. P. (2001). Identity as an analytic lens for research in education. Review of Research in Education, 25(2000-2001), 99-125. http://dx.doi.org/10.2307/1167322

Guerrero Nieto, C. H., \& Meadows, B. (2015). Global professional identity in deterretorialized spaces: A case study of a critical dialogue between expert and novice nonnative English speaker teachers. PROFILE Issues in Teachers' Professional Development, 17(2), 13-27. http://dx.doi.org/10.15446/profile.v17n2.44194

Han, J., \& Yin, H. (2016). College English curriculum reform in Mainland China: Contexts, contents and changes. Asian Education Studies, 1(1), 1. http://dx.doi.org/10.20849/aes.v1i1.9

Ilieva, R. (2010). Non-native English-speaking teachers' negotiations of program discourses in their construction of professional identities within a TESOL program. Canadian Modern Language Review/ La Revue canadienne des langues vivantes, 66(3), 343-369. http://dx.doi.org/10.3138/cmlr.66.3.343 
Kim, Y. Y. (1994). Beyond cultural identity. Intercultural Communication Studies, IV(1), 3-23.

Liu, J. (1999). Nonnative-English-speaking professionals in TESOL. TESOL Quarterly, 33(1), 85-102. http://dx.doi.org/10.2307/3588192

Llurda, E., \& Huguet, A. (2003). Self-awareness in NNS EFL primary and secondary school teachers. Language Awareness, 12(3-4), 220-231. http://dx.doi.org/10.1080/09658410308667078

Menard-Warwick, J. (2008). The cultural and intercultural identities of transnational English teachers: Two case studies from the Americas. TESOL Quarterly, 42(4), 617-640. http://dx.doi.org/10.1002/j.1545-7249.2008.tb00151.x

Menard-Warwick, J. (2011). Chilean English teacher identity and popular culture: Three generations. International Journal of Bilingual Education and Bilingualism, 14(3), 261-277. http://dx.doi.org/10.1080/13670051003797466

Moran, P. R. (2001). Teaching culture: Perspectives in practice. Boston, MA: Heinle \& Heinle.

Moussu, L., \& Llurda, E. (2008). Non-native English-speaking English language teachers: History and research. Language Teaching, 41(03), 315-348. http://dx.doi.org/10.1017/s0261444808005028

Norton, B. (2006). Identity as a sociocultural construct in second language research. TESOL in Context [Special Issue], 22-23, 1-10.

Nugroho Widiyanto, Y. (2005). The making of a multicultural English teacher. English Teaching: Practice and Critique, 1(4), 106-117.

Ortaçtepe, D. (2015). EFL teachers' identity (Re)construction as teachers of intercultural competence: A language socialization approach. Journal of Language, Identity \& Education, 14(2), 96-112. http://dx.doi.org/10.1080/15348458.2015.1019785

Pavlenko, A. (2003). "I never knew I was a bilingual": reimagining teacher identities in TESOL. Journal of Language, Identity \& Education, 2(4), 251-268. http://dx.doi.org/10.1207/S15327701JLIE0204_2

Phan, L. H. (2007). Australian-trained Vietnamese teachers of English: Culture and identity formation. Language, Culture and Curriculum, 20(1), 20-35. http://dx.doi.org/10.2167/lcc324.0

Phan, L. H., \& Phan, V. Q. (2006). Vietnamese educational morality and the discursive construction of English language teacher identity. Journal of Multilingual Discourses, 1(2), 136-151. http://dx.doi.org/10.2167/md038.0

Reis, D. S. (2011). Non-native English-speaking teachers (NNESTs) and professional legitimacy: A sociocultural theoretical perspective on identity transformation. International Journal of the Sociology of Language, 2011(208). http://dx.doi.org/10.1515/ijsl.2011.016

Rivers, D. J., \& Ross, A. S. (2013). Idealized English Teachers: The Implicit Influence of Race in Japan. Journal of Language, Identity \& Education, 12(5), 321-339. http://dx.doi.org/10.1080/15348458.2013.835575

Samimy, K. K., \& Kurihara, Y. (2006). Nonnative speaker teachers. In K. Brown (Ed.), The Encyclopedia of Language and Linguistics (2nd ed., Vol. 8, pp. 679-686). Oxford, England: Elsevier.

Selvi, A. F. (2011). The non-native speaker teacher. ELT Journal, 65(2), 187-189. http://dx.doi.org/10.1093/elt/ccq092

Sercu, L. (2002). Implementing intercultural foreign language education. Belgian, Danish and British teachers' professional self-concepts and teaching practices compared. Evaluation and Research in Education, 16(3), 150-165. http://dx.doi.org/10.1080/09500790208667015

Sercu, L. (2006). The foreign language and intercultural competence teacher: the acquisition of a new professional identity. Intercultural Education, 17(1), 55-72. http://dx.doi.org/10.1080/14675980500502321

Sercu, L., Bandura, E., Castro, P., Davcheva, L., Laskaridou, C., Lundgren, U., . . Ryan, P. (2005). Foreign language teachers and intercultural competence: An international investigation. Clevedon, England: Multilingual Matters.

Trent, J. (2012). Becoming a teacher: the identity construction experiences of beginning English language teachers in Hong Kong. The Australian Educational Researcher, 39(3), 363-383. http://dx.doi.org/10.1007/s13384-012-0067-7

Tsui, A. B. M. (2007). Complexities of identity formation: a narrative inquiry of an EFL teacher. TESOL 
Quarterly, 41(4), 657-680. http://dx.doi.org/10.1002/j.1545-7249.2007.tb00098.x

van Compernolle, R. A., \& Williams, L. (2013). Sociocultural theory and second language pedagogy. Language Teaching Research, 17(3), 277-281. http://dx.doi.org/10.1177/1362168813482933

Varghese, M., Morgan, B., Johnston, B., \& Johnson, K. A. (2005). Theorizing language teacher identity: Three perspectives and beyond. Journal of Language, Identity, and Education, 4(1), 21-44. http://dx.doi.org/10.1207/s15327701jlie0401_2

Weisman, E. M. (2001). Bicultural identity and language attitudes: Perspectives of four Latina teachers. Urban Education, 36(2), 203-225. http://dx.doi.org/10.1177/0042085901362004

Wenger, E. (1998). Communities of practice: Learning, meaning and identity. Cambridge, England: Cambridge University Press.

Wette, R., \& Barkhuizen, G. (2009). Teaching the book and educating the person: challenges for university English language teachers in China. Asia Pacific Journal of Education, 29(2), 195-212. http://dx.doi.org/10.1080/02188790902857180

White, C., \& Ding, A. (2009). Identity and self in e-language teaching. In Z. Dörnyei \& E. Ushioda (Eds.), Motivation, language identity and the L2 self (pp. 333-349). Bristol, England: Multilingual Matters.

Wu, B., \& Wurenbilige, W. (2012). University English teachers' identity in minority area: A case study of a trilingual teacher in China. International Journal of English Linguistics, 2(2). http://dx.doi.org/10.5539/ijel.v2n2p91

Yang, S., \& Bautista, D. D. (2008). Reflection, arts, and self - inquiry: A letter to other for negotiating Korean English teacher identity. Reflective Practice, 9(3), 293-305. http://dx.doi.org/10.1080/14623940802207170

\section{Copyrights}

Copyright for this article is retained by the author(s), with first publication rights granted to the journal.

This is an open-access article distributed under the terms and conditions of the Creative Commons Attribution license (http://creativecommons.org/licenses/by/3.0/). 